\title{
O último conto policial de Borges e o que havia no labirinto ${ }^{1}$
}

\author{
Pablo M. Ruiz ${ }^{2}$
}

\section{Resumo}

Este ensaio propõe duas hipóteses diferentes, conquanto relacionadas. Por um lado, sugere que o conto "Abenjacan, o Bokari, Morto em Seu Labirinto" foi escrito de modo que o papel do detetive deve estar a cargo do leitor. Esse é um modelo que o próprio Borges propusera no "Exame da obra de Herbert Quain". Sustento que a solução oferecida ao final do conto é apenas hipotética e proponho uma possível solução alternativa. Por outro lado, situo tal conto no quadro mais geral da poética narrativa de Borges e de sua concepção do leitor. A idéia central é que tal poética deve ser vista como a invenção de um novo leitor, que surge da combinação de dois modelos de leitura fortes e em muitos sentidos opostos: aqueles proporcionados pelo texto sagrado, e pelo gênero policial. Sustento que esta combinação sem precedentes é uma das principais contribuições de Borges à renovação do conto como gênero, e que sua virtuosa execução naquele conto permite reavaliá-lo como uma peça central na sua narrativa.

\section{Palavras-chave}

Borges, literatura argentina, conto, gênero policial, modelos de leitura.

1 Agradeço a Pedro Meira Monteiro por sua cuidadosa tradução.

2 Professor-visitante no Departament of Spanish and Portuguese, Columbia University. Estados Unidos da América. E-mail: pmr2127@columbia.edu 


\title{
Borges' Last Detective Story and What Was in the Labyrinth
}

\author{
Pablo M. Ruiz
}

\section{Abstract}

This essay makes two different, though related claims. On the one hand, it suggests that Borges' detective story "Ibn Hakkan Al-Bokhari, Dead in his Labyrinth" was written in such a way that the role of the detective has to be played by the reader. This is a model Borges himself had proposed in "Examination of the Works of Herbert Quain." I claim that the solution at the end of the story is only provisional, and I propose a possible alternative solution. On the other hand, I place this story within the broader frame of Borges' narrative poetics and conception of the reader. I advance the idea that this poetics should be seen as the invention of a new reader, one that arises from the combination of two strong, and in many ways opposed, reading models: those provided by the sacred text and by detective fiction. I claim that this unprecedented combination is one of Borges' main contributions to the renewal of the short story as a literary genre, and that its virtuosic execution in this story leads us to reconsider it as a major piece in the body of Borges' narrative.

\section{Keywords}

Borges, Argentine literature, short story, detective fiction, reading models. 


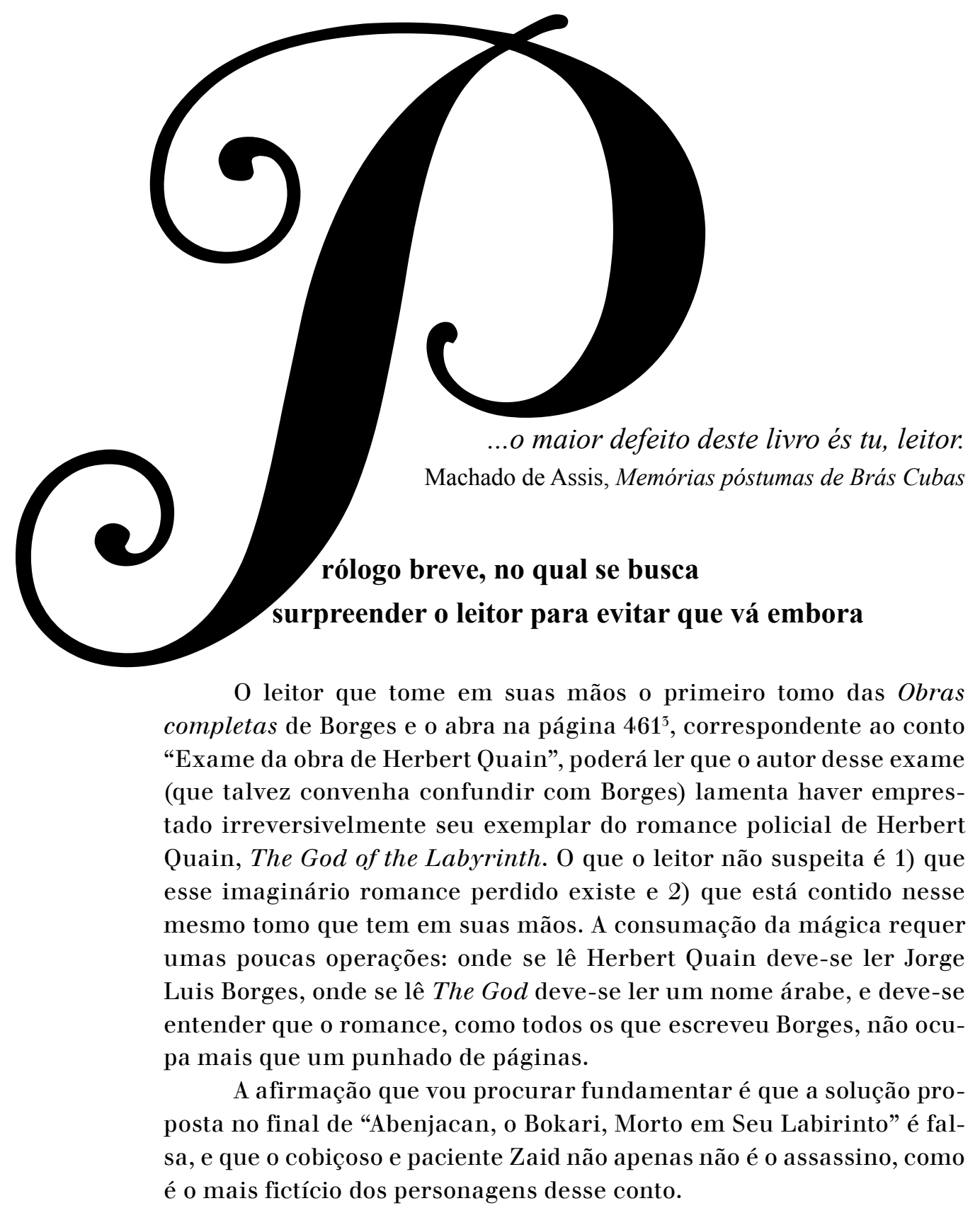

3 BORGES, Jorge Luis. Obras completas. Barcelona: Emecé, 1989-96. 4 v. 


\section{Capítulo prescindível em que se abusa da paciência do leitor, conquanto se lhe ofereça em troca uma possível explicação de si mesmo}

Elejamos um conto qualquer de Borges, por exemplo "As ruínas circulares". Tomemos a primeira parte da primeira frase desse conto: "Ninguém o viu desembarcar na unânime noite." Interroguemos essa cadeia de signos. Por que a primeira palavra é ninguém? Porque o conto postula uma realidade regida pelo sonho, na qual a identidade se dissolve em cadeias de sonhos numa regressão infinita, que fazem de cada $e u$ uma sombra de outro eu que o precede. Essa primeira palavra, portanto, longe de ser casual, cifra e condensa em uma única unidade a totalidade do conto, que se pode ler como uma explicação de sua palavra inaugural. Por que vem em seguida o verbo ver? Porque justamente essa última realidade, como sombra e sonho, esconde-se, como nas doutrinas de Platão, atrás das aparências visíveis enganosas: a visão encarna o questionamento epistemológico que o conto postula, nossa incapacidade de conhecer o universo confiando na percepção dos sentidos de nossa limitada condição humana: "ninguém o viu", quer dizer, ninguém viu o universo como realmente é. E por que esse adjetivo surpreendente aplicado à noite, unânime? Em primeiro lugar, porque a noite é noite para todos (e noite aqui deve entender-se como a escuridão que completa a impossibilidade de ver, isto é, de conhecer). Mas também porque etimologicamente essa palavra significa "uma alma", o que por um lado remete à unidade essencial do $e u$ contraposta à concepção sancionada pelo sentido comum de individualidades diferenciadas, que o conto postula como ilusórias, e por outro lado conecta o relato com as concepções filosóficas e teológicas monistas, desde Pitágoras e Platão até Averroes e Spinoza, passando pelo budismo, pela doutrina das emanações dos gnósticos, por cabalistas como Isaac Luria e por místicos como Angelus Silesius.

Et cetera.

Este exercício de interpretação, de rigor incerto e de extensão potencialmente ilimitada, e que nem mesmo os maiores expertos poderiam distinguir de sua desapiedada paródia, dificilmente será considerado completamente vão pelos leitores avisados de Borges. A razão é a seguinte: estes leitores têm a suspeita, ou inclusive a convicção, de que esses textos foram escritos para serem submetidos a essa leitura. Tudo em Borges, crêem estes leitores - aprenderam estes leitores -, é potencialmente uma alusão, uma referência, um indício, uma autocitação, uma chave secreta. Nenhum deles consideraria a possibilidade de aplicar procedimentos similares aos contos de, digamos, Maupassant, 
Tchekov ou Hemingway, sem duvidar da estabilidade mental de quem cometa tal empreendimento.

Dificilmente, também, terão deixado de reconhecer o modelo de meu exercício e de sua conclusão, na conferência de Borges sobre a cabala. Nessa conferência de julho de 1977, Borges apresenta o procedimento mediante uma espécie de redução ao absurdo, ao imaginar um cabalista lendo o Quixote e submetendo suas primeiras palavras a operações de permutação das letras, e de consignação de quantidades numéricas, de combinação com outras palavras isoladas, tratando de deduzir sentidos a partir dessas operações. Cerca de cinqüenta anos antes, em 1931, Borges publicou o ensaio "Uma vindicação da cabala”. Nele se lê:

Imaginemos, de acordo com a teoria pré-agostiniana de inspiração verbal, que Deus dita, palavra por palavra, o que se propõe dizer. Essa premissa (que foi a que assumiram os cabalistas) faz da escritura um texto absoluto, onde a colaboração do acaso é calculável em zero ${ }^{4}$.

O que poucas vezes se observa quando se reproduz esse fragmento popularmente citado, é que ele aparece imediatamente após um parágrafo no qual Borges lista três modelos de escritor: o jornalista, o poeta e o escritor intelectual, apresentados nesta ordem, ordem que deriva do acaso decrescente dos textos que elaboram. Borges agrega a essa tríade o último termo da série e seu limite inalcançável: a mente absoluta de Deus, que elude de um modo infalível qualquer manifestação do acaso.

Desde essa reflexão inicial, Borges imaginou a cabala não somente como um modelo de leitura e uma metáfora do pensamento, mas também como todo um modelo a partir do qual construir-se como escritor. Seu próprio lugar na lista, há que buscá-lo em uma quarta posição, que corresponderia ao escritor que esforça o seu intelecto e a si mesmo em direção a esse limite absoluto de quem escreve um texto impermeável à contingência e estritamente necessário; escritor que aspira a construir um texto que idealmente seja "um mecanismo de infinitos propósitos, de variações infalíveis, de revelações que ameaçam, de superposições de luz", e que justifique ser interrogado até ao absurdo.

Uma passagem quase idêntica à da conferência sobre a cabala se encontra, recordará o leitor, na conferência sobre o conto policial. Ali é outra vez o Quixote o texto submetido a uma leitura que lhe é alheia: desta vez a de um leitor do gênero policial que suspeita de cada dado trazido pelo texto e elabora conjeturas inúteis a cada passo. Aqui tam-

4 BORGES, Jorge Luis. Obras completas, Op.cit. p. 211. 
bém é importante circunscrever a citação: nessa conferência, Borges situa o conto policial inventado por Poe dentro do contexto mais amplo da concepção da criação literária de Poe, uma concepção a que poderíamos chamar intelectual, que consiste em postular a mente, e não o espírito, como agente da composição, e que Poe enuncia pela primeira vez na história da literatura ${ }^{5}$. No começo dessa conferência, Borges assinala que Poe não é apenas o inventor de um gênero, mas também de um tipo de leitor: a distinção é pertinente, já que um gênero novo não necessariamente implica um novo tipo de leitor, e um novo tipo de leitor pode surgir a partir de textos já existentes, como no caso dos cabalistas $^{6}$. O gênero policial, assim como a cabala, está muito presente na reflexão literária que Borges empreende nos primeiros anos trinta e que define sua poética, seu próprio arquétipo de escritor. Do policial, atraem-no sobretudo a necessidade de inventar com rigor, a exigência de planejar e desenhar a trama, e também o novo leitor, o novo modo de ler que impõe o gênero, que implica, para dizê-lo com a fórmula de Coleridge, algo parecido a abolir a suspensão da incredulidade.

Também Borges, como procura ilustrar o começo desta seção, é o inventor de um novo tipo de leitor. Um leitor que, para simplificá-lo num esquema, surge da combinação dos procedimentos da cabala, que conferem potencialmente sentido plural a cada parte do texto, com a desconfiança e a suspicácia do leitor do gênero policial, habituado às armadilhas que o escritor lhe desdobra. Borges inova ao estender essas armadilhas e levá-las do interior das tramas regidas pelas convenções de um gênero às convenções mesmas que determinam os limites entre gêneros; notadamente, as que distinguem o conto do ensaio, isto é, a ficção da realidade.

Este leitor se move entre dois perigos que o ameaçam: o extremo de credulidade e o extremo de suspicácia. Avancemos até à anedota.

5 Mas que decerto está implícita na Poética de Aristóteles e na épica e na tragédia clássicas, na arte minuciosa dos trovadores provençais e, notoriamente, na Comedia de Dante.

6 Este leitor já havia sido inventado na China mais de dois mil anos antes e reinventado mil anos depois. A primeira invenção, produziram-na os autores e escrutadores do I Ching, por volta do século XI a.C. A segunda foi mais complexa e requereu as seguintes três etapas, a cargo da Escola do Novo Texto no século I a.C.: primeiro canonizar Confúcio como um sábio infinito; depois atribuir-lhe os Anais da primavera e o outono, um árido registro anônimo dos fatos cotidianos da corte do reino de $\mathrm{Lu}$, ocorridos entre os séculos VII e V a.C.; o último passo, que deu forma aos dois mil anos posteriores de história chinesa ao ser adotado como doutrina oficial do Império, foi postular que esses registros ("tal dia recebeu-se um ministro do reino vizinho", "tal dia choveu”, "tal dia o imperador se reuniu com seus assessores", etc.) cifravam o conhecimento completo das dez mil coisas do céu e da terra, seu passado e seu porvir. 
1) Na introdução a certo manual sobre a história das ciências do meio ambiente, o autor discute o problema da classificação das ciências naturais, e cita Foucault citando a classificação dos animais que Borges simula citar de uma enciclopédia chinesa em "O idioma analítico de John Wilkins". Este autor transcreve fascinado a classificação completa, exibe-a como modelo possível de classificação e, sem duvidar da enciclopéida chinesa, julga-a "particularmente estranha e arbitrária". Uma involuntária colaboração do leitor, e Borges agregou um objeto ao mundo. 2) Em um seminário na Universidade de Buenos Aires, dedicado à relação entre Borges e a filosofia, discutia-se "A biblioteca de Babel". Alguém mencionou o conto "A biblioteca total", do escritor alemão Kurd Lasswitz. O professor não pôde evitar o tipo de sorriso que se oferece a um menino que pergunta pelos reis magos, e explicou que esse autor era mais um dos autores fictícios inventados por Borges, e até mencionou um artigo em que se "demonstrava" que o nome era uma combinação borgeana da palavra alemã Witz, "engenho", e de outra palavra francesa de significado similar. Outra involuntária colaboração do leitor, e Borges apagou um escritor da história. Esse combate surdo entre Borges e o mundo, entre Borges e seu leitor, esse combate desigual no qual o leitor cai nas armadilhas que não vê ou evita cair nas armadilhas que não existem, é constante e se trava a cada dia.

Talvez haja que buscar a origem remota, ao menos como símbolo, na primeira publicação de sua vida. Aos 9 anos de idade, Borges faz uma tradução do conto "Um príncipe feliz", de Oscar Wilde, e essa tradução é publicada. Todos a atribuem ao Borges errado, ao pai. Assim fácil engana-se o leitor. O leitor de Borges, poderíamos exagerar, nasce lendo mal. Os episódios posteriores que essa atribuição equívoca prefigura já são lenda: seus amigos encomendando na Inglaterra exemplares do romance The Approach to Al-Mu'tasim, leitores de Sur buscando exemplares dos livros de Pierre Menard, um jornalista espanhol perguntando pela casa de Buenos Aires onde se pode ver o Aleph.

Borges, poderíamos dizer com certa tolerância pela hipérbole, passou a vida escrevendo a Bíblia, quer dizer, escrevendo textos que engendrassem um leitor equivalente ao leitor engendrado pela Bíblia; textos que tolerassem e até exigissem ser submetidos a essa leitura excessiva, agoniada e perigosa, e que incorporassem ademais o caráter premeditado da trama e os procedimentos que incitassem a leitura incrédula e suspicaz inventada pelo gênero policial; textos que tivessem por ideal inalcançável e modelador a aspiração ao acaso zero. Dito de outro modo, Borges passou toda a vida inventando o seu leitor, o grande personagem da sua literatura, seu golem, nós mesmos. 


\section{Capítulo chamado "A intrincada e complexa teia de aranha", ou o que o leitor estava esperando se todavia não foi embora}

\section{As pistas}

Na página 462 do mencionado primeiro tomo das Obras completas, lemos a seguinte descrição do plano do romance policial de Herbert Quain:

Há um indecifrável assassinato nas páginas iniciais, uma lenta discussão nas páginas intermediárias, uma solução nas últimas. Já aclarado o enigma, há um parágrafo largo e retrospectivo que contém esta frase: Todos acreditaram que o encontro entre os dois jogadores de xadrez havia sido casual. Essa frase dá a entender que a solução está errada. O leitor, inquieto, revisa os capítulos pertinentes e descobre outra solução, que é a verdadeira. O leitor desse livro singular é mais perspicaz que o detetive.

O conto a que pertence este parágrafo é de 1941. A mesma idéia já havia sido exposta por Borges na revista El hogar de 15 de abril de 1938, numa resenha do romance policial Excellent Intentions, de Richard Hull:

Um dos projetos que me acompanham, que de algum modo me justificarão perante Deus, e que não penso executar (porque o prazer está em entrevê-los, não em levá-los a cabo), é o de um romance policial um pouco heterodoxo. (O último detalhe é importante, porque entendo que o gênero policial, como todos os gêneros, vive da contínua e delicada infração de suas leis.)

Concebi-o uma noite, uma das gastas noites de 1935 ou de 1934 [...]. Eis aqui meu plano: urdir um romance policial do tipo corrente, com um indecifrável assassinato nas primeiras páginas, uma lenta discussão nas páginas intermediárias e uma solução nas últimas. Logo, quase no final, agregar uma frase ambígua - por exemplo: "e todos acreditaram que o encontro entre esse homem e essa mulher havia sido casual" - que indicasse ou deixasse supor que a solução era falsa. O leitor, inquieto, revisaria os capítulos pertinentes e encontraria outra solução, a verdadeira. O leitor desse livro imaginário seria mais perspicaz que o "detetive". ${ }^{7}$

7 BORGES, Jorge Luis. Textos cautivos. Buenos Aires: Tusquets, 1986. p. 227-228. 
Antes ainda, em 30 de outubro de 1936, na resenha de Half-Way House de Ellery Queen, também publicada na revista El Hogar, Borges escreve o que talvez seja o germe da idéia:

Na história do gênero policial [...] os romances de Ellery Queen importam um desvio, ou um pequeno progresso. Refiro-me a sua técnica. O romancista sói propor um esclarecimento vulgar do mistério e deslumbrar seus leitores com uma solução engenhosa. Ellery Queen propõe, como os outros, uma explicação nada interessante, deixa entrever (ao fim) uma solução belíssima, de que se enamora o leitor, refuta-a e descobre uma terceira, que é a correta: sempre menos estranha que a segunda, mas de todo imprevisível e satisfatória. ${ }^{8}$

A idéia que expõem os dois parágrafos anteriores surge de deter o procedimento de Queen ${ }^{9}$ antes da revelação da terceira solução e deixar ao leitor a possibilidade de descobri-la. Desde que não tenha se enamorado da solução "belíssima”. E falsa.

\section{O problema}

Escondida no virtuosismo arrazoador de Unwin e na vertigem dos duplos, dos rostos destruídos e das identidades trocadas que surpreendem o leitor, a belíssima solução que o matemático propõe sofre do seguinte defeito: obrigar-nos a aceitar que Zaid, movido pela cobiça e contra toda razoável verossimilhança, decide dedicar anos de sua vida e o dinheiro de seu tesouro a executar um complexo plano para matar Abenjacan, imediatamente após não ter aproveitado a oportunidade de fazê-lo de um modo expedito e gratuito no deserto do Egito. Ainda que Unwim, diante da objeção de Dunraven, trate de corrigir a motivação e sugerir desviá-la da cobiça em direção ao ódio e ao temor, haveria que supor-se o mesmo ódio e o mesmo temor no momento em que Zaid decide não matar seu primo, o que faz persistir o problema e faz com que o resultado siga sendo pouco convincente (no que diz Unwin deixa-se entrever essa dúvida: "se tua hipótese é correta..."). Outros indícios, formais, secundários, isto é, externos à estrita motivação da trama, apontam para a falsidade dessa solução. Dunraven a escuta, respondendo com um "silêncio pensativo, ou incrédulo". Unwin é matemático, e no conto que Borges considerava o melhor dos policiais

8 Idem, ibidem. p. 40.

9 Não sei se já se notou a possibilidade de ler, no nome de Herbert Quain, o de Ellery Queen, cuja similitude não é necessário destacar. 
de Poe - "A carta roubada" - e que Unwin menciona no começo do conto, Dupin insiste que a matemática por si só é insuficiente, e que requer o complemento da poesia para que a capacidade analítica seja máxima. O nome de Unwin sugere em inglês a negação do êxito, e não possui o $\mathrm{D}$ do nome do amigo poeta para poder desentranhar (unwind) o mistério; e no nome do poeta, Dunraven, sobra essa mesma letra que o impede de ser quase unravel, sinônimo de unwind, e de poder também desentranhar, desvelar o enigma: o D que os entrelaça sugere que caíram presos em sua própria rede. Os amigos deveriam fundir-se como o significado de seus nomes e ser um para chegar à verdadeira solução, mas separados são incapazes de fazê-lo. Onde buscar uma solução alternativa, a terceira e verdadeira solução?

\section{A conjetura}

O conto, bem visto, tem dois finais. A página que lhe segue, que inclui a história "Os dois reis e os dois labirintos", pronunciada pelo reitor Allaby do púlpito, é também, ainda que de modo ambíguo, parte do conto. A pergunta do leitor suspicaz, do leitor submerso na incredulidade, do leitor treinado por Borges, é: por que esse discurso não está incluído no conto, e aparece transposto ao final? Ou, de outra forma: por que dar a última palavra do conto ao reitor Allaby, cujo nome, por outro lado, se pronuncia como alibi, que em inglês significa "escusa", ou propriamente álibi? Admitamos a hipótese de que se trata de uma pista e voltemos ao conto.

Segundo o relato de Duraven, o reitor Allaby teve um encontro privado com Abenjacan quando começava a construção do labirinto, encontro que se encerra com a visita de Abenjacan a Allaby como resposta ao seu sermão condenatório. Três anos depois, cometidos os assassinatos, o reitor testemunha diante das autoridades o que Abenjacan lhe disse nesse encontro. E essa é a história dos dois primos, um rei e o outro vizir, que fogem do deserto do Egito com um escravo e um leão, como conseqüência de uma revolta que os depõe e os obriga a escapar com o tesouro, e que desemboca no assassinato de Zaid por parte de Abenjacan, o que por sua vez resulta no fantasma de Zaid ameaçando em sonhos vingar-se do primo traidor e matá-lo algum dia com simétrica destruição de rostos. Há outro testemunho da veracidade dessa estória? Sim, há uma verificação de uma parte do relato oferecida pelo Times de Londres, que informa sobre o episódio da rebelião e a posterior derrota que obriga os primos a fugir. Mas como sabemos dessa verificação? Através de Allaby, que diz ter ido a Londres buscar a 
informação em jornais antigos. E como sabemos o que ocorreu no dia dos assassinatos? Já não nos surpreende encontrar o nome de Allaby novamente: ele é quem diz haver recebido um aterrorizado Abenjacan, outra vez sem testemunhas, com a notícia de que já haviam sido assassinados o escravo e o leão e pedindo ajuda às autoridades. Abenjacan parte antes de obter uma resposta, tão desesperado quanto chegou, e no dia seguinte Allaby se dirige ao labirinto apenas para verificar, quando chega, que já também Abenjacan jaz morto e que o tesouro foi roubado. Segunda hipótese: Allaby mente.

Há no conto confirmações do relato de Allaby não providas por ele mesmo? O único que pode considerar-se como tal é a chegada do barco em que o fantasma de Zaid (ou Abenjacan, na solução de Unwin) chega à Inglaterra. Leiamos esse parágrafo, parte do relato de Dunraven:

Três anos após a construção da casa, ancorou ao pé das colinas o Rose of Sharon. Não fui dos que viram esse veleiro e é possível que na imagem que tenho dele influam esquecidas litografias de Aboukir ou de Trafalgar, mas penso que era desses barcos muito trabalhados que não parecem obra de construtor de navio mas de carpinteiro e menos de carpinteiro que de ebanista. Era (se não na realidade, pelo menos nos sonhos) polido, escuro, silencioso e veloz, tripulado por árabes e malaios. ${ }^{10}$

"Se não na realidade, pelo menos nos sonhos." Trata-se de um barco que ele não viu e que substitui em sua recordação por imagens vistas em livros, e sobre o qual não há no conto nenhum testemunho direto. Pareceria que apenas existe no relato de Allaby, que é também quem no dia seguinte verifica a partida do barco. Uma vez mais, Allaby é a única fonte de informação. Hipótese secundária que reforça a segunda hipótese: o Rose of Sharon é um barco imaginário, ou quando menos um barco real de itinerário imaginário, e cuja chegada a Cornwall não ocorreu senão no relato de Allaby. Há outro detalhe: quando Unwin afirma que a história contada por Dunraven é mentira, este "prorrompeu em palavrões e invocou o testemunho do filho mais velho do reitor (Allaby, parece, havia morrido) e de todos os vizinhos de Pentreath". Suponho que o mais importante dessa citação também esteja dentro do parêntese e é o verbo "parece". O que talvez sugira essa incerteza é que Allaby pode haver dissimulado sua morte ou forjado sua desaparição, talvez para fugir em paz com o tesouro. Terceira hipótese e possível solução do enigma: Allaby é o assassino.

10 BORGES, Jorge Luis. O Aleph. Trad. Flávio José Cardozo. Rio de Janeiro: Globo, 1985. p. 101. 


\section{A corroboração}

Para tratar de confirmá-la só falta um passo: reconstruir uma história alternativa que seja coerente com a hipótese. Essa reconstrução poderia ser assim: pouco depois da chegada de Abenjacan, e já iniciada a construção alarmante, Allaby pronuncia seu sermão condenatório. Abenjacan visita o reitor no dia seguinte e eles mantêm uma reunião privada. De algum modo, Abenjacan consegue autorização para prosseguir e terminar a construção de sua fortaleza. Três anos se passam, e um dia Allaby se dirige ao labirinto, mata com um disparo o leão, o escravo e Abenjacan, destroça-lhes as faces e rouba o tesouro. Todo o resto é o que ele inventa como pretexto diante das autoridades: o passado de rei no Egito, Zaid (o primo vizir), a rebelião, a fuga, o assassinato e a posterior ameaça, as notícias do Times, o barco. Quem é então Abenjacan, ou o homem a que o povo chama Abenjacan, o homem que constrói uma casa desmedida na qual se encerra durante três anos até que o matem? Podemos conjeturar um pirata ou um contrabandista, alguém que foge, sem que saibamos de onde, com um tesouro talvez roubado ou acumulado mediante atividades turvas, sobre quem é fácil imaginar inimigos que o perseguem e dos quais se protege com o labirinto. Constrói sua fortaleza na costa e com uma janela que dá para o mar, quem sabe para poder controlar a chegada dos barcos com os quais concretiza seus negócios, barcos nos quais também poderiam chegar seus inimigos. E por isso nunca sai de sua casa e é somente o escravo quem se encarrega das operações. Escravo? Pode ser que o seja, mas já não o sabemos; também pode ser um homem que trabalha a soldo, ou um cúmplice que recebe parte dos lucros. Só o leão sabemos que é um leão.

Esta alternativa não deixa de apresentar dificuldades. Por exemplo, como faz Allaby para não perder-se no labirinto e encontrar suas vítimas? Podemos supor que a chave esteja na reunião secreta. Não é inverossímil supor que, para autorizar a construção que acaba de condenar, Alliby exigisse algum plano ou descrição do labirinto. Também cabe perguntar-se pela motivação dos crimes. A resposta, há que buscá-la no sermão e no tesouro desaparecido: o resultado é uma combinação de intolerância ou ódio religioso e de cobiça, ou de mero desprezo que a cobiça pode haver multiplicado. A cobiça sozinha não basta para explicar um reverendo assassino, mas seu sermão apresenta o ódio religioso e moral como motivação possível: um mouro, um bárbaro, um não cristão que erige um edifício monstruoso para concertar atividades ilícitas, gera não apenas a condenação, como também a aversão extrema do reitor. Outra pergunta é por que os rostos desfigurados. Não era suficiente para Alla- 
by matá-los e roubar o tesouro? Na explicação de Unwin, Zaid necessita a face apagada de Abenjacan para evitar que se veja que o que morreu não é ele, que todos consideravam ser Abenjacan; e os outros dois rostos desfigurados, como explica Unwin, previnem a suspeita da mudança de identidades. E o leitor deduz que é por isso que Zaid incluiu o detalhe do rosto em seu relato a Allaby no primeiro encontro. Mas para a conjetura do Allaby assassino há que encontrar uma nova justificação, que poderia ser a seguinte: por um lado, Allaby consegue fortalecer a verossimilhança da história do assassinato entre primos e da posterior ameaça de vingança: os rostos desfigurados não são mais que a concretização dessa vingança profetizada; por outro lado, cumprem a função essencial, do ponto de vista de Allaby, de tornar quase inimaginável a hipótese de que o culpado é ele: um crime tão brutal é cometido por bárbaros, ainda mais se eles vêm encarnados em fantasmas enfurecidos e vingadores.

Um problema solucionado é que agora se explica a visita desesperada de Abenjacan/Zaid a Allaby pedindo ajuda, uma vez mortos o escravo e o leão. Na solução de Unwin essa visita é debilmente justificada, já que Zaid não tem verdadeira necessidade de fabricar testemunhos de sua inocência se imediatamente depois dos crimes tem que fugir do país; teria sido mais fácil fugir diretamente. Mas desde o ponto de vista de Allaby, inventar essa visita é necessário como justificação de sua própria visita posterior ao labirinto, não por certo com a intenção de verificar as mortes, mas sim de executá-las.

É revelador cotejar o texto de "Abenjacan" com a tradução ao inglês feita pelo próprio Borges, em colaboração estreita com Norman Thomas Di Giovanni, e que aparece no volume The Aleph and other stories $^{11}$. A comparação revela uma série de modificações, duas das quais são particularmente relevantes. Por um lado, a referência à possibilidade de que Allaby morrera desaparece por completo, como também desaparece a menção a seu filho. Onde Borges escreve "Dunraven prorrompeu em palavrões e invocou o testemunho do filho mais velho do reitor (Allaby, parece, havia morrido) e de todos os vizinhos de Pentreath", Borges, diferentemente, escreve:

Dunraven broke out in a torrent of strongly flavored language and said that all the population of Pentreath could bear witness to the truth of what he had told and that if he had to make up a story, he was a writer after all and could easily have invented a far better one. ${ }^{12}$

11 BORGES, Jorge Luis. The Aleph and other stories 1933-1969. Ed. and trans. Norman Thomas Di Giovanni and Jorge Luis Borges. New York: E. P. Dutton, 1970.

12 Idem, ibidem. p. 121. 
Por que esta alteração? Suponho que Borges terá notado que sugerir a morte de Allaby era demasiado impreciso tendo em conta o quartel transcorrido entre os assassinatos e o relato de Dunraven, que fazia com que as causas, seja da morte ou da desaparição, se multiplicassem em demasiadas possibilidades irrelevantes para a trama. Também é possível que o incomodasse haver agregado sem necessidade mais um personagem, o filho de Allaby, sem função no relato.

A outra modificação é quase invisível e mais significativa. Referindo-se ao barco Rose of Sharon, Borges escreve: "[Allaby] observou, no outro dia, que o veleiro já havia zarpado (rumo a Suakin, no Mar Vermelho, averiguou-se depois)." O texto entre parêntesis, na tradução, diz: "bound to the Red Sea port of Suakin, he later learned". Esta modificação se explica mais facilmente: o impessoal "averiguou-se" permitiria dar um estatuto de realidade ao barco diante da possibilidade de que sejam outras pessoas as que averiguaram, enquanto a tradução insiste que é Allaby a única fonte de informação.

Em suma, os estritos feitos de "Abenjacan", prescindindo dos detalhes, podem reduzir-se a este esquema narrativo: chega a um povoado inglês um estrangeiro rico, talvez contrabandista ou delinqüente, e o reitor local, por simples ódio ou cobiça, o mata. Todo o resto é fumaça retórica, teia de aranha verbal, fabulação. Se isto fosse matemática, diríamos que o teorema ficou demonstrado.

\section{Capítulo a que poderíamos chamar "Magias parciais de 'Abenjacan, o Bokari, Morto em Seu Labirinto'”, no qual se submete o leitor a uma duvidosa elucidação de símbolos, alegorias e outros incômodos}

\section{A construção policial}

Certa vez Borges disse do gênero policial que era "talvez o mais artifical de quantos a literatura compreende"15. Não poderia haver emitido um elogio maior. Para Borges o policial é a matéria perfeita para, enquanto artifício total que por sua vez exige o minucioso planejamento da trama, moldar suas formas narrativas ${ }^{14}$. Borges limitava

13 Idem. Obras completas. Op. cit., v. 4. p. 432.

14. Poderia agregar-se que o recurso ao gênero policial é uma das diversas soluções que Borges encontrou (tendo refutado o romance) para um problema estético crucial: como escrever filosofia fazendo literatura. Não podia haver encontrado um melhor símbolo para essa preocupação que este gênero literário de puro artifício, centrado na busca da verdade. 
sua contribuição ao gênero a três contos: "O jardim dos caminhos que se bifurcam", "A morte e a bússola" e "Abenjacan, o Bokari, Morto em Seu Labirinto". Haveria que adicionar, talvez, o conto "A aproximação a Almotásim", cronologicamente prévio aos demais, que consiste no comentário crítico a um romance policial inexistente ${ }^{15}$.

Uma primeira observação sobre o que estes textos têm em comum, e que se pode ver como um caso particular de um hábito recorrente em Borges, é que ele sempre faz o policial, gênero menor, popular, relativamente novo, de circulação massiva, publicado em jornais ou em edições baratas e desprezado pelas elites cultas, chocar-se com uma grande tradição literária, canônica e consagrada, sofisticada, de estirpe centenária e de caráter "exótico" para o leitor ocidental. Em “A aproximação a Almotásim”, essa grande tradição é a poesia mística persa dos sufis islâmicos, composições plenas de alusões, linguagem hermética e alegorias cifradas. Em "O jardim dos caminhos que se bifurcam”, é a tradição do romance chinês clássico, construções de grande complexidade e múltiplos recursos técnicos, e cujas obras canônicas se medem em não menos de duas mil páginas nas edições das traduções modernas. Em "A morte e a bússola”, essa tradição é, desde logo, a da mística judaica representada pela cabala, portadora das concepções de texto total e de leitura múltipla e exaustiva. Em "Abenjacan”, pode distinguir-se, por um lado, a relação com a tradição da narrativa árabe (de fontes persas e originalmente hindus) de As mil e uma noites, que Borges considerava uma espécie de modelo canônico da narração pura; mas também se podem ver outras conexões com a literatura não policial que se indicarão nas seções seguintes, conquanto eu antecipe que incluem a transformação das referências explícitas em procedimentos formais que aludem indiretamente àquelas tradições.

Os três contos (excluindo agora "Almotásim") têm em comum algo evidente, e é que o encontro entre o assassino e a vítima, e o assas-

15 Remeto o leitor interessado na relação entre Borges e o policial aos excelentes estudos de José Fernández Vega, Cristina Parodi e Pablo Brescia. Este último, centrado en "Abenjacan", resume boa parte da crítica prévia dedicada a este conto. (Agora que escrevo esta nota, e perseguido pelo temor da inevitável redundância e da inevitável repetição, pergunto-me se não tinha que haver aproveitado para renovar o gênero e haver escrito o ensaio mais breve do mundo, com uma única linha veloz e certeira, que dissesse simplesmente "Allaby, parece, é o culpado”.) BRESCIA, Pablo A. J. De policías y ladrones: Abenjacán, Borges y la teoría del cuento. Variaciones Borges, v. 10, p. 145-166, 2000.; FERNÁNDEZ VEGA, José. Una campaña estética. Borges y la narrativa policial. Variaciones Borges, v. 1. p. 27-66, 1996.; PARODI, Cristina. Borges y la subversión del género policial. In: FRANCO, Rafael Olea (Ed.). Borges: desesperaciones aparentes y consuelos secretos. México: El Colegio de México, 1999. p. 77-97. 
sinato conseguinte, produz-se, nos três casos, no centro do labirinto: o jardim e a casa de Stephen Albert, a quinta de Triste-le-Roy, a casalabirinto de Abenjacan. Não seria recomendável adentrar agora a simbologia do labirinto; basta indicar que Borges considerava os contos policiais como tais (cf. "Os labirintos policiais e Chesterton", resenha de 1935 que inclui uma preceptiva do gênero), pelo que estamos diante de outra instância da utilização por parte de Borges de símbolos que reproduzem no conteúdo as características da forma, como também ocorre com os espelhos ou os duplos, o que não faz mais que ratificar o caráter de artifício e de construção verbal dessas ficções ${ }^{16}$.

A resolução do enigma restitui "Abenjacan” à lógica do policial borgeano, ou ao menos à lógica de “A morte e a bússola”, seu único outro conto com detetive. Assim como Lönnrot se perde na rede simbólica que armam sua sofisticação e sua inteligência erudita, que exigem que a realidade se comporte como uma ficção artificial e elegante, também Unwin acaba seduzido pela elegância intelectual de sua solução, que por sua vez captura Dunraven. Borges dá ao leitor a possibilidade de ser Treviranus e postular que em um assassinato do qual há um único informante, que ademais exibiu desprezo pela vítima, esse é então o principal suspeito.

A revelação de uma terceira trama oculta nas outras duas transforma o conto em uma maquinaria verbal de extremo virtuosismo e precisão, ao tecer essa terceira história com os fios das outras duas de modo que ela termine invisível ${ }^{17}$. Essas tramas e as referências que as acompanham tecem também uma história do gênero policial segundo Borges, quer dizer, do clássico policial de enigma: primeiro temos a referência ao que Borges considerava o melhor conto policial do inventor do gênero, Poe; depois temos o enigma que sugere uma solução sobrenatural (primeira trama, que inclusive poderia ser lida como um conto de terror de Poe) e a proposta de Unwin que a substitui por uma solução racional: esta é a segunda trama, que responde ao modelo de conto policial de Chesterton; depois temos a referência àquela que Borges considerava a melhor solução para o problema do quarto fechado (a de Zangwill)

16 Evitarei ocupar-me da função dos símbolos na narrativa de Borges em geral, o que seria inútil dada a grande quantidade de estudos disponíveis, aos quais remeto o leitor.

17 Uma amostra mais desse virtuosismo, dão-na as frases ao final do conto. Transcrevo as palavras de Unwin: "Zaid, se tua hipótese é correta, agiu premido pelo ódio e pelo medo e não pela cobiça. Roubou o tesouro e depois compreendeu que não era o essencial. O essencial era que Abenjacan perecesse.” Diz Dunraven, encerrando o conto: "Sim, [Zaid] foi um vagabundo que, antes de ser ninguém na morte, recordaria ter sido um rei ou ter fingido ser um rei, algum dia." Faça o leitor as seguintes substituições: onde se lê Zaid na primeira citação, leia-se Allaby; onde se lê Zaid na segunda, leia-se Abenjacan. A motivação de Allaby e a identidade de Abenjacan, explicadas. 
e a utilização da técnica tomada de Ellery Queen. Essa história do gênero tem um final implícito na terceira trama: por acaso não é o leitor como detetive o feito central do gênero, que desde que nasceu viveu da possibilidade de que o leitor pudesse competir com o detetive, de que também pudesse participar da história e eventualmente ser o detetive? A regra de que todos os elementos necessários para a solução do enigma devem ter-se apresentado ao leitor antes de oferecer a solução, regra sempre respeitada e defendida por Borges e pelos melhores cultores do policial $^{18}$, não é mais que a formulação de tal identificação como constitutiva do gênero. As demais regras (limite de personagens, economia de meios, solução necessária) podem ver-se como uma ética que gira em torno dessa regra central, os procedimentos válidos para levá-la a cabo. Concretizar por completo a fusão entre o detetive e o leitor é, de algum modo, esgotar o gênero. A história do policial segundo Borges, poderíamos postular, nasce em 1841 com "Os crimes da rua Morgue" de Poe e termina cerca de um século depois com "Abenjacan, o Bokari, Morto em Seu Labirinto", o conto com o qual Borges se despediu do gênero e a que chamou seu canto do cisne, e que quiçá o seja do gênero mesmo.

A pergunta que resta formular é: como pôde esta terceira possibilidade permanecer oculta durante cinqüenta anos, com a obra de Borges submetida ao escrutínio microscópico quase universal? A resposta é múltipla, mas creio que se centra numa técnica literária e em sua execução magistral: a paródia. No comentário a este conto que figura em The Aleph, Borges se refere à cada vez maior necessidade de parodiar à medida que trabalha com a trama: "The more I worked on it, the more hopeless the plot seemed and the stronger my need to parody. What I ended up with I hope will be read for its humor"19. O que podia entender-se como uma paródia do gênero policial, agora se entende, também e sobretudo, como uma paródia de si mesmo. Borges, digamolo assim, inventa uma história deliberadamente borgeana para que não se veja que essa história é falsa; escreve uma história destinada ao leitor de Borges, destinada a que esse leitor a reconheça, para que não veja que a história verdadeira é outra: a auto-paródia como armadilha. A eficácia desse procedimento é extraordinária: a culpabilidade de Allaby acaba por revelar-se surpreendente ainda quando Allaby não seja apenas um em uma lista de possíveis culpados apresentados para distrair e confundir o leitor, senão o único.

18 Com algumas exceções em Sherlock Holmes, que Borges impiedosamente denuncia em suas resenhas.

19 BORGES, Jorge Luis. The Aleph and Other Stories, Op.cit. p. 274. 


\section{Aforma}

"Abenjacan" não é apenas um conto policial em que o detetive é o leitor. É também um texto no qual os procedimentos de construção destinados a esse leitor postulado, destinados a criar um texto que tende ao acaso nulo e que permite ser interrogado de múltiplas maneiras e em múltiplos níveis, estão elevados a seu extremo de execução técnica. Nesta e nas seguintes seções me proponho a indagar alguns desses procedimentos $^{20}$.

Já se assinalou o que vários comentadores observaram: os nomes dos personagens se prestam à interpretação. Unwin e Dunraven são um par oposto, matemático e poeta, mas unificados pela capacidade analítica tomada de Poe e cifrada em seus nomes, sinônimos imperfeitos. Também se pode notar que unwind e unravel significam a idéia de destecer, desfiar, e isto os relaciona com a simbologia da teia de aranha que propõe a epígrafe. Unwin usa esse símbolo do sonho do relato de Allaby como chave que lhe permite encontrar sua solução, mas o labirinto de Abenjacan não é a única teia de aranha do conto destinada a atrair e prender: o conto mesmo é essa teia, que Unwin e Dunraven não fazem mais que reforçar em seu tecido, na armadilha à qual estão cada vez mais enredados. Também podemos ver, invocando certa tolerância interpretativa, a cadeia UnwinDunraven como análogo formal do texto do conto e, assim como essa cadeia necessita que a última letra seja modificada e lida como $l$ em lugar de $n$ para chegar a unwind-unravel, também o último elo do conto deve ser lido de outra maneira para chegar à solução: o discurso de Allaby não como história senão como pista. Para recriar uma frase familiar ao leitor de Borges, a última letra do nome deve ser articulada ${ }^{21}$.

Esses mecanismos, insisto, não deveriam ser reduzidos a caprichos ou divertimentos, mas sim vistos sobretudo como manifestações da emoção central que guiava Borges como contista: a aversão pela contingência e arbitrariedade, a necessidade de dar a cada elemento

20 Observemos que uma das frases mais repetidas pela crítica de Borges é "Borges tomou X e o levou até ao limite”. X pode ser um gênero literário, uma idéia, um recurso estético, um conceito, uma doutrina filosófica, um atributo humano, um argumento teológico, um enigma metafísico. Pode ser o policial, os paradoxos de Zenão, a enumeração, o infinito, o idealismo, a linguagem, a natureza de Judas, o tempo. Borges (se toleramos o símile mitológico) visto como um Midas das idéias, que o que toca com sua inteligência esgota conceitualmente, entende em todas as suas possibilidades e transforma em ouro estético.

21 Este jogo simbólico com os nomes (note ademais o leitor que Dunraven inclui raven, o corvo de Poe) multiplica sua eficácia ao verificar-se que Allaby, Unwin e Dunraven são nomes habituais na Inglaterra, como se Borges tivesse tido a preocupação de havê-los inventado séculos antes para garantir a elegância de seu conto. 
um sentido possível e uma justificação, de guiar com a mente o processo criativo e de dotar cada texto do máximo de densidade verbal ${ }^{22}$. E que deveriam ser vistos também como parte da construção desse personagem imaginário que é o leitor, como seus atributos, suas expectativas, seus desejos. Eles foram originalmente a causa desse leitor e dispostos para criá-lo; em “Abenjacan”, são a sua confirmação definitiva e sua culminação. Vejamos outros desses atributos.

As obras atribuídas a ambos os personagens no começo do conto em realidade o cifram. Dunraven escreverá uma obra "que seus contemporâneos quase não poderiam escandir”, isto é, interpretar, decifrar. Unwin, por seu turno, havia publicado um trabalho sobre "o teorema que Fermat não escreveu à margem de uma página de Diofanto": Borges tampouco escreve a solução, senão que nos deixa a chave à "margem" do conto, nessa página extra que é o seu verdadeiro final.

O diálogo que mantêm no começo do conto é outra descrição autoreferencial. Por um lado, Unwin propõe não multiplicar os mistérios, que devem ser simples, e oferece os exemplos de "A carta roubada" de Poe e do quarto fechado de Zangwill. A solução do conto acaba por ser simples, a referência ao conto de Poe adverte o leitor sobre a impossibilidade de que um matemático ou um poeta possam dar com a solução, e o quarto fechado de Zangwill dá a chave da conduta de Allaby. Como Borges mesmo o descreveu em diálogo com M. E. Vázquez, referindo-se ao subgênero policial do assassinato cometido em um quarto fechado:

Uma das soluções mais brilhantes é a do escritor judeu-inglês Israel Zangwill em 'The Bigbow Murders'[...] A solução que dá para o crime cometido é que o que descobre, ou simula descobrir o crime, é o que o comete" 23 .

Por outro lado, Dunraven se inclina pela complexidade, aduzindo como exemplo o universo. E isto também está descrevendo o conto, não com respeito à solução do enigma senão à sua complexidade for-

22 Borges nos oferece mais de uma confirmação destas afirmações. Diz em uma fala sobre seus contos: "Eu não creio, contrariamente à opinião de Edgar Allan Poe, que a arte, a operação de escrever, seja uma operação intelectual” BORGES, Jorge Luis. Así escribo mis cuentos. In: ZAVALA, Lauro (Ed.). La escritura del cuento. México: UNAM, 1995. p. 32. (Teorías del cuento, II). E, em uma conferência: "Aí está a teoria contrária à romântica, enunciada por um grande poeta romântico, dom Edgar Allan Poe; é a teoria da poesia como um ato mental, como um ato intelectual. Entretanto, eu creio que essa teoria é falsa." . El poeta y la escritura, In: Borges en la Escuela Freudiana de Buenos Aires. Buenos Aires: Agalma, 1993. p. 107.

23 VÁSQUEZ, María Ester. Borges, sus días y su tiempo. Buenos Aires: Javier Vergara, 1984. p. 135. 
mal, à construção elaborada até ao detalhe microscópico das tramas entrelaçadas, e à multiplicação das referências e dos símbolos.

\section{Os duplos}

Há três pares de duplos em “Abenjacan”. Em primeiro lugar, o mais imediato, o de Unwin e Dunraven. Sobre esta duplicação haveria que observar que os dois são personagens reais no conto, e que são dois que não logram ser um. Em segundo lugar, o par Abenjacan/Zaid, do qual haveria que observar que, enquanto um é real no conto, o outro é uma ficção, e que é um que se transforma em dois. Em terceiro lugar, o par assassino/detetive, neste caso Allaby/leitor, no qual um é real no conto e o outro na realidade exterior à ficção, e são dois entre os quais se estabelecem certas identificações ${ }^{24}$.

Sobre o primeiro par caberia agregar ao já dito que, por um lado, é uma evidente paródia da tradicional dupla de detetive e companheiro, inaugurada por Poe con Dupin e seu amigo, e consagrado por Conan Doyle com Sherlock Holmes e Watson. Por outro lado, caberia dizer que, como matemático e poeta, Unwin e Dunraven são também figuras da razão e da intuição, da mente e do espírito, do clássico e do romântico, arquétipos sob os quais Borges gostava de alinhar os escritores como representantes de duas concepções opostas da literatura: também a literatura, infere-se, requer a fusão dos antagonistas para ser completa. Ademais, enquanto leitores/intérpretes da história de Allaby, Unwin e Dunraven são também leitores de Borges. E representam os dois extremos do leitor típico de Borges, os perigos do crédulo e do suspicaz. O excesso de candidez poética de Dunraven o leva a povoar o mundo com fantasmas vingadores. O excesso de suspicácia analítica de Unwin o leva a consubstanciar na realidade um personagem de ficção, a substituir uma credulidade por outra.

Do par Abenjacan/Zaid notou-se o simbolismo das iniciais, o A e o $\mathrm{Z}$ que cifram o começo e o fim, a circularidade etc., e que remetem a outras invenções de Borges com forte carga simbólica como o Aleph e o Zahir (e a outras significações que o leitor interessado poderá seguir explorando, e associar, por exemplo, a esses nomes tomados do fun-

24. Alguns aspectos da literatura em geral podem pensar-se em pares, não somente no evidente duo autor/leitor, mas também na lógica da crítica. Como escreve Gabriel Castillo: "O melhor crítico literário é o que pensa como o escritor a que lê; o pior é o que imita o seu estilo". E explica: "O bom tende a ser dois: desdobra-se no escritor para lê-lo e se afirma em si mesmo para examiná-lo; o mau é menos que um: dissolvido na voz do autor que o fascina, não é mais que seu símio mimético" CASSTILLO, Gabriel. Los tamaños del sentido. Buenos Aires: Simurg, 1998. p. 612. 
do da ordenação alfabética que aparecem justamente em "O Aleph": o trio formado pelos italianos Zunino, Zungri, Zunni; ou com o nome da heroína judia Emma Zunz), e deveria ler-se na chave auto-paródica assinalada. Auto-paródia que se completa com as figuras do covarde e do valente, com a relação de traição, com o fato de que os dois são o mesmo, de que intercambiam identidades etc.

Vejamos o terceiro par. Num conto em que o detetive é o leitor, a simetria impõe que o assassino seja o escritor. Pelo que não estranha encontrar elementos que permitem a identificação de Allaby como alter ego borgeano: é um solitário em sua biblioteca e um homem de leitura curiosa, com predileção pelas histórias orientais e que se revela, uma vez deduzida sua função no conto, como algúem capaz de fabular histórias caracteristicamente borgeanas e que desenha ficções para 0 engano, equivalentes verbais do labirinto arquitetônico e destinadas, como a teia de aranha, a extraviar e prender ${ }^{25}$. É um consumado fabulador que lê, o que simetricamente leva a pensar o leitor como alguém que escreve, o que é certo ao menos enquanto, no seu papel de detetive, ele reconstrói a história do crime que resolve. Depois de tudo, para voltar à lógica cabalística, ambos estão a uma única letra de distância, a inicial que separa reitor de leitor.

Cabe observar que os dois últimos pares surgem como ramificação do par Allaby/Abenjacan como assassino/vítima, par que permanece oculto até que se encontra a solução. Abenjacan submerge na ficção, pela sua identificação com um rei fictício e por seu desdobramento em Zaid, personagem duplamente fictício; Allaby emerge em direção à realidade, pela sua identificação com Borges e por sua relação de par com o leitor, personagem real.

Há outra correspondência que se pode pensar a partir da identificação de Allaby com Borges: quando publica "Os dois reis e os dois labirintos" como texto independente, doze anos antes de sua inclusão em "Abenjacan", Borges porventura não sabe que esse texto será parte de outro conto; quando pronuncia seu sermão condenatório, três anos antes dos assassinatos, Allaby porventura não sabe que vai assassinar, ou tentar assassinar, Abenjacan. $O$ paralelismo do escritor e o assassino se projeta sobre a relação entre o conto e os crimes.

25 Umberto Eco, cuja contribuição à literatura policial consiste em haver enriquecido "A morte e a bússola" com quinhentas páginas de pedagogia medieval, localiza no final de seu romance o duplo de Borges, o assassino e bibliotecário Jorge de Burgos, no centro do labirinto. Até desta originalidade Borges o privou. 


\section{Espelhos verbais}

No pós-escrito de 1952 ao epílogo de 1949, agregado à segunda edição de $O$ Aleph, em que o conto aparece pela primeira vez em formato de livro, Borges escreve:

Abenjacan, o Bokari, Morto em Seu Labirinto não é (me asseguram) memorável apesar de seu título tremebundo. Podemos considerá-lo uma variação de "Os dois reis e os dois labirintos" que os copistas intercalaram em As mil e uma noites e que o prudente Galland omitiu. ${ }^{26}$

Com perversa inocência, enquanto simula jogar com as falsas atribuições, Borges simultaneamente dá uma pista e estende a armadilha. É claro que está insistindo em que os dois textos devem ler-se juntos, mas é igualmente claro que é sobretudo a história falsa de Abenjacan e Zaid que convida a ler-se como uma variação de "Os dois reis". Esta começa em um labirinto artificial, construído pelo homem, e termina no labirinto espontâneo do deserto; na narração de Allaby ocorre o contrário: os primos fogem primeiro através do deserto e terminam em um labirinto de construção humana. Na primeira, o rei árabe é traído mas consegue vingar-se e matar o rei da Babilônia; na segunda, Zaid é traído mas seu fantasma consegue vingar-se e matar Abenjacan. Que as duas histórias se correspondam como duas faces de um mesmo relato, agora o sabemos, não se explica por uma casualidade injustificada, mas porque ambas foram inventadas pelo mesmo personagem, Allaby.

Mas também em relação com a história dos crimes do reverendo Allaby, "Os dois reis" é uma variação: em ambos os casos temos uma parábola moral na qual quem constrói o labirinto é castigado e morre por causa dessa vaidade. (Outro modo por que se dá essa relação de variação entre as duas histórias se indica na seção seguinte.)

Os títulos de ambas as histórias podem ver-se também como uma espécie de chave encoberta: de um rei (Abenjacan) e um labirinto, se passa a dois reis e dois labirintos: o título do conto se refere a um só, o do sermão de Allaby se refere a dois; isto é, está dizendo que a duplicação falsa dos reis (um Abenjacán a que se soma Zaid) é obra de Allaby.

A última frase de "Os dois reis" seria uma chave inútil: "A glória esteja com Aquele que não morre" se refere, lido na tradição islâmica, a Deus. No contexto do conto, tomando em conta que Abenjacan morre nas mãos do reitor, refere-se a Allaby, quer dizer, a Borges. Sem em-

26 BORGES, Jorge Luis. O Aleph, Op.cit. p. 146. 
bargo, nada impede aplicá-la ao fantasma de Zaid na história inventada por Allaby, ou a Zaid na solução de Unwin. A relação Deus/Allaby/ Borges se pode ver também no título atribuído ao romance de Quain: o deus do labirinto não é decerto Abenjacan, senão o reitor Allaby, quer dizer, Borges. Não estou sugerindo uma secreta megalomania, mas sim a cifra de uma poética, de uma concepção da literatura e do escritor. Vejamos de passagem, já que mencionamos o romance de Quain, a variação magistral (e enganosa) que se produz na forma: o que na descrição do romance é "um parágrafo largo e retrospectivo" que contém uma frase ambígua que sugere a falsidade da solução, em "Abenjacan" é um discurso que não é retrospectivo em seu conteúdo senão em sua cronologia dentro do relato, e cuja ambigüidade, longe de ser explícita, também é apenas formal, desde que está simultaneamente dentro e fora do relato, desde que é e não é parte do conto.

Em relação a "A morte e a bússola", em "Abenjacan" a cabala passa de parte da trama a parte da forma. Do mesmo modo, os espelhos enfrentados desde a quinta de Triste-le-Roy, que talvez simbolizem as simetrias do conto, também passam à forma em "Abenjacan”, conto feito de dois textos que se enfrentam como espelhos.

Por último, haveria que notar que a história de Abenjacan e Zaid, confabulada por esse leitor de As mil e uma noites que é Allaby, é também espelho de um dos modelos narrativos dos contos árabes, no qual o rei Harún al-Raschid sai disfarçado, para não ser reconhecido, a percorrer as ruas noturnas de Bagdad em companhia de seu vizir. Allaby/Borges transforma Abenjacan no reflexo simétrico: em alguém anônimo a quem ele disfarça como rei, e para quem inventa um vizir não protetor, mas sim ameaçador e vingativo ${ }^{27}$. Se ademais tomamos em conta que Borges entreteve-se desde o princípio em atribuir "Os dois reis e os dois labirintos" a As mil e uma noites, o jogo de espelhos está completo: "Abenjacan" se reflete em "Os dois reis" que se reflete em As mil e uma noites que se refletem em "Abenjacan". Que se reflete em As mil e uma noites que se refletem em "Os dois reis" que se reflete em "Abenjacan".

27 Lembremos ainda que As mil e uma noites são a fonte do álibi e também o motivo pelo qual o álibi pode ser eficaz: está dirigida a gente que, como seguramente Dunraven, crê que o Oriente é uma terra de reis e vizires, de tesouros e espíritos assassinos porque a leitura de As mil e uma noites os preparou para crer nisso. Isto é: Allaby também recorre à paródia para enganar. 


\section{A alegoria}

Para continuar com o hábito de dar instruções de leitura que são também armadilhas de leitura, Borges comenta na já mencionada edição em inglês: "I certainly can't expect anyone to take seriously or to look for symbols in such pictorial whims as a black slave, a lion in Cornwall, a red-haired king [...]"28. O treinado leitor de Borges não necessita mais nada para tomar a sério imediatamente esse caprichos pictóricos. O conto oferece com claridade estas disposições de cores: o leão é "a fera da cor do sol”, o escravo é "o homem da cor da noite" e Abenjacan tem barba avermelhada ${ }^{29}$; mais adiante, Unwin se refere a Abenjacan como "o homem vermelho" ${ }^{30}$. Esta justaposição de vermelho, amarelo e negro perdeu algum comentarista nos labirintos da alquimia $^{31}$. Que nesses terrenos haja alguma chave não é impossível, mas prefiro uma interpretação mais razoável: são as cores da bandeira da Alemanha.

Entendido desta maneira, o simbolismo cromático agrega uma significação nova a "Abenjacan": o assassinato do trio "alemão" que conformam o leão, o escravo e o rei, executado pelo inglês Allaby, transforma o conto em uma alegoria da derrota da Alemanha nas mãos da Inglaterra nas guerras mundias. Se se presta atenção ao começo do conto, Unwin e Dunraven, premonitoriamente "fartos de um mundo sem a dignidade do perigo", se encontram durante a primeira tarde do verão de 1914, isto é, 21 de junho de 1914. O encontro final de ambos em Londres se dá três dias depois, ou seja, 24 de junho. Quatro dias mais tarde, na manhã de 28 de junho de 1914, dar-se-á o assassinato em Sarajevo que desencadeará a Primeira Guerra Mundial. Se consideramos a cronologia não do conto senão da leitura do conto, do processo que termina com a decifração do enigma, e tendo em conta também que o relato se publica pela primeira vez em 1951, então "Abenjacan” começa com o estalido da Primeira Guerra e termina com a derrota definitiva da Alemanha: o arco das duas guerras mundiais resta coberto pela alegoria. Novamente, a tradução ao inglês já mencionada colabora com a hipótese. O texto original refere assim o que dizia a gente de Pentreath diante da construção de Abenjacan: "entre os mouros são usadas tais

28 BORGES, Jorge Luis. The Aleph and other stories, Op. cit. p. 274.

29 Idem. OAleph, Op.cit. p. 99.

30 Idem, ibidem. p. 105.

31 Leio, em um comentário de cuja referência poupo o leitor: "Estas três cores combinadas dão por resultado uma inconfundível cor marrom. Borges não podia não sabê-lo. O simbolismo se impõe com claridade: se trata de uma evidente homenagem ao padre Brown, o inesquecível detetive chestertoniano.” 
casas, mas não entre cristãos". A tradução ao inglês traz: "Amongforeigners such houses must be common, but not here in England" ${ }^{2}$. A nova oposição entre estrangeiros e ingleses faz com que possa ser literal a interpretação alemães/ingleses, e não somente figurada como no caso de mouros e cristãos.

O labirinto carrega agora outra significação. Recorde o leitor que Unwin e Dunraven discutem sobre o minotauro. Leiamos o que Borges diz a Richard Burgin, a respeito de "A casa de Asterion":

Senti que haveria algo verdadeiro na idéia de um monstro que quer que o matem, que necessita que o matem, não é? [...] Deve ter se sentido agradecido ao herói que o matou. Durante a Segunda Guerra Mundial escrevi muitos artigos sobre a guerra, e num deles disse que Hitler seria derrotado porque intimamente desejava ser derrotado ${ }^{33}$.

Hitler é Asterion, isto é, o monstro no centro do labirinto, isto é, Abenjacan: o homem que se encerra no labirinto a esperar, quase voluntariamente, seu assassino.

Esta leitura agrega não somente um atenuante à brutalidade de Allaby, mas também uma identificação mais entre o reitor e Borges: Allaby/Borges, o solitário e curioso leitor na biblioteca de livros ingleses, se transforma no defensor da Inglaterra - e da tradição literária inglesa - diante da ameaça da barbárie nazista. Deste modo Borges (se não na realidade, em seus sonhos) dá forma à sua aspiração de um destino de coragem e de herói épico. Borges completa a humorada (e alarga, outra vez, a armadilha) no comentário de The Aleph, onde qualifica o reitor Allaby de timorous, tímido, temeroso.

No começo do conto, quando se diz que Dunraven comporá uma epopéia que seus contemporâneos não poderão escandir, também se diz que o tema ainda não lhe havia sido revelado. Agora podemos aventar que Dunraven todavia não conhece o tema de seu futuro poema porque essa epopéia é a que revela a alegoria, e ele não pode conhecêla antes do começo da guerra.

Além disso, também "Os dois reis" pode ser lido em chave alegórica. O mesmo Borges explica, no comentário que figura em The Aleph: "After some twenty-five years, I am beginning to suspect that the king of Babylon, with his lust for winding ways and devious complexity, stands for civilization, while the Arabian king stands for unrelieved

32 BORGES, Jorge Luis. The Aleph and Other Stories, Op. cit. p. 117.

33 BURGIN, Richard. Conversations with Jorge Luis Borges. New York: Avon Books, 1968. p. 56-7. 
barbarism" ${ }^{34}$. E aqui se vê o outro modo por que estas duas histórias são variações recíprocas: em ambas se produz o choque entre a civilização e a barbárie, e enquanto no sermão de Allaby o bárbaro termina vencendo, seus assassinatos bárbaros são a vitória do civilizado.

A relação explícita entre policial e alegoria que rege "A aproximação a Almotásim" também é deslocada a um nível interno de elaboração formal. E o mesmo ocorre com o significado concreto da alegoria em relação a "O jardim de caminhos que se bifurcam". Numa passagem da confissão de Yu Tsun, espião chinês a serviço do governo alemão, lemos: "Não o fiz pela Alemanha, não! Não me importa um país bárbaro, que me obrigou à abjeção de ser um espião. Ademais, eu sei de um homem da Inglaterra - um homem modesto - que para mim não é menos que Goethe" ${ }^{55}$. E este significado concreto da alegoria em "Abenjacan" corresponde, por sua vez, ao significado do policial para Borges, que propunha como justificação do gênero sua racionalidade e sua ordem, seu aporte para salvar o mundo numa época de caos.

\section{"Multum in parvo"}

O leitor, em "Abenjacan", está previsto e inscrito de distintos modos, além do papel de detetive que lhe está potencialmente consignado. Recapitulemos: Dunraven o menciona ao referir-se às convenções que o leitor espera que se respeitem; uma só letra o separa de seu duplo, o reitor; é a figura que completa o jogo de pares dos personagens. Dunraven e Unwin são eles mesmos caricaturas do leitor de Borges. E também está previsto de um modo perverso: contam-se-lhe histórias borgeanas, histórias que aprendeu a reconhecer como borgeanas, para que não veja que essas histórias são falsas, para enganá-lo. Creio ver um modo mais em que o leitor está aludido.

Como conseqüência da auto-paródia referida, o leitor não deixa de notar que em "Abenjacan" estão reunidos, se não todos, quase todos os signos de Borges, como em uma espécie de summa de sua poética: o labirinto, os duplos, a biblioteca, As Mil e uma noites, os punhais, os arquétipos de Platão, a infâmia, a paródia, Dante, o infinito, não um tigre mas um leão, a cifra autobiográfica, a matemática, o xadrez, a coragem e a covardia, os livros ingleses, o deserto, a traição. Dunraven batiza Abenjacan "Rei de Babel", e em "Os dois reis", um deles é o rei da Babilônia: essas cidades também estão indicando os respectivos contos da biblioteca e da loteria. A discussão sobre o minotauro remete a "A

34 BORGES, Jorge Luis. The Aleph and other stories, Op. cit. p. 271.

35 Idem. Obras completas, Op.cit., v. 1, p. 473. 
casa de Asterion", a simbologia alegórica do destino alemão a "Deutsches Requiem", a traição e a posterior redenção a "Tema do traidor e do herói", o labirinto-casa de cor vermelha antecipa a casa de "There are more things", também há uma epígrafe do Corão em "O milagre secreto" e o tesouro dos Nibelungos aparece repetido em "O Zahir". Borges parece inclusive haver querido ampliar esta teia de aranha feita de fios de sua própria obra quando comenta o valor alegórico de "Os dois reis" em The Aleph. Surpreendentemente, termina esse comentário trasladando o enfrentamento dos dois reis ao enfrentamento do gaucho e do porteño como encarnações do bárbaro e do civilizado: a história argentina, a gauchesca, Buenos Aires, Sarmiento, a planície, pronto encontram seu espaço nessa summa.

O conjunto da enumeração anterior sugere, por sua vez, ver em “Abenjacan” um Aleph, uma espécie de Aleph literário no qual vemos vertiginosamente desfilar a obra de Borges, condensada nesta esfera de palavras que é “Abenjacan”, uma espécie de limitada eternidade, já não espacial mas verbal. O destinatário deste Aleph é, por certo, o leitor de Borges, capaz de reconhecê-lo. Se Borges esteve anos construindo, inventando e desafiando seu leitor, em "Abenjacan" parece oferecer-lhe como reconhecimento, quase como oferenda, este modesto fragmento de esférica eternidade literária.

"O Aleph" talvez não esteja incluído em "Abenjacan" mais que deste modo indireto, quiçá porque o Aleph é o que tudo inclui, razão por que "Abenjacan" teria que estar incluído em "O Aleph", conto publicado seis anos antes da primeira publicação de "Abenjacan”. Recordemos que, em “O Aleph”, esse personagem a que Borges chama Borges tem a oportunidade de ver aquela minúscula parte do universo que é tão grande como o universo. Releiamos o começo da enumeração da visão do Aleph: "Vi o populoso mar, vi a aurora e a tarde, vi as multidões da América, vi uma prateada teia de aranha no centro de uma negra pirâmide, vi um roto labirinto (era Londres) [...]"36. O leitor de Borges se surpreende: não é essa teia de aranha que provoca o sonho de Abenjacan dentro de uma tumba do Egito, que é quase uma definição de pirâmide? E não aparece Londres, em “Abenjacan”, descrita como um labirinto, agora roto como conseqüência da guerra, uma Londres bombardeada? ${ }^{37}$ Podemos ver nesta alusão velada a confirmação

36 Idem. OAleph, Op.cit., p. 133.

37 Devo este achado a Daniel Scarfó, bem como uma série de considerações sobre o vermelho e seus símbolos, que transcrevo parcialmente: "O vermelho está no centro de tudo. Abenjacan é vermelho, o labirinto que constrói é vermelho, o barco se dirige ao Mar Vermelho, o nome do barco é uma flor vermelha e até o ouro dos nibelungos se fez vermelho. Também em 'A morte e a bússola', como se indicou 
de que Borges estabeleceu uma comunicação entre os dois contos, que se apontam e se incluem reciprocamente. Podemos propor uma natureza dupla de "Abenjacan": é simultaneamente um conto de Borges e o universal, o arquétipo dos contos de Borges, seu prodigioso Aleph ${ }^{38}$.

Bioy Casares indica como contribuição de Borges à história do conto o descobrimento dos problemas da metafísica como possibilidade temática ${ }^{39}$. Ítalo Calvino indica como novidade o recurso à descrição e ao comentário de livros inexistentes ${ }^{40}$. Ricardo Piglia, ao expor a tese segundo a qual o conto consiste sempre em duas histórias ${ }^{41}$, uma visível e uma secreta, destaca que Borges inova fazendo da construção da história secreta o tema de seus $\operatorname{contos}^{42}$. Caberia agregar a essas inovações os aspectos formais e de construção que "Abenjacan" exemplifica e que a acumulação incessante de interpretações de seus relatos demonstra: Borges traz ao conto, pela primeira vez na história do gênero, procedimentos até então reservados à composição de poesia e à leitura de textos sagrados. Esses procedimentos, que Borges deriva do modelo de leitura da cabala, em conjunção com o modelo do gênero policial, o levam a conceber o ideal do conto como um texto sem contingência, no que tudo está, ou deve tender a estar, calculado, previsto e justificado. Mas não só no sentido de Poe, que predicava que tudo em um texto literário deve estar submetido ao efeito final buscado, mas

tantas vezes, o vermelho é a cor dominante, cifrada redundantemente nos nomes de Lönnrot e de Red Scharlach. A lista pode multiplicar-se (a casa de 'There are more things', a última coluna da 'Parábola do palácio', os volumes do Quixote mencionados na Autobiografia, o último tigre em 'A máquina de pensar de Raimundo Lulio’ etc.). Muitas vezes aparece refletido em sinônimos: carmesim, escarlate, colorado, bermejo [...] As conotações de sangue e violência são o sentido imediato, e talvez se possa defender uma simbologia epistemológica, mas é especialmente importante o vermelho como cor da criação: o nome de Adão significa 'homem' e ‘vermelho' no hebraico antigo da Bíblia e dos cabalistas, e no uso que faz Borges, especialmente no policial, há que ver a referência à cabala e ao golem, e sobretudo um modo de cifrar a idéia do escritor como deus criador" (comunicação privada).

38 Borges comenta a vasta ambição deste conto (que, recordemos, o justificaria perante Deus) em seu diálogo com Antonio Carrizo. Diante da pergunta por "Abenjacan”, Borges responde: "Isso vem a ser... Eu creio que é um conto policial. Não é muito bom. Poderíamos passar a outro, eh?” CARRIZO, Antonio. Borges, el memorioso. Buenos Aires: Fondo de Cultura Económica, 1982. p. 236.

39 BIOY CASARES, Adolfo. Reseña de: BORGES, Jorge Luis El jardín de senderos que se bifurcan. Sur, v. 92, p. 60-63, 1942.

40 CALVINO, Ítalo. Seis propuestas para el próximo milenio. Madrid: Siruela, 1989.

41 Uma das virtudes desta tese é transformar o conto em uma forma do contraponto musical. Desde esta perspectiva, “Abenjacan”, ao incluir uma terceira história entre as dobras das outras duas, mostra uma arquitetura de complexidade comparável às mais trabalhadas polifonias de Palestrina ou de Gesualdo, às fugas perfeitas de Bach.

42 PIGLIA, Ricardo. Crítica y ficción. Buenos Aires: Siglo XX, 1990. 
num sentido mais amplo, que agrega a essa exigência uma outra: a da possibilidade de uma pluralidade de sentidos e níveis de significação, cifrados em símbolos, referências, nomes, recursos formais, alusões. O que podemos chamar, para confundi-lo com uma fórmula, a poética do acaso zero. Dado que esses procedimentos estão estreitamente conectados com a postulação de um ideal de leitor, ao ponto de que eles procedem dessa postulação, e dado que neste relato esse leitor tem reservado um papel único, não é excessivo propor "Abenjacan, o Bokari, Morto em Seu Labirinto" como o conto paradigmático dessa poética, e portanto como um conto central na narrativa de Borges. Um conto que seus leitores afirmavam que não era especialmente memorável, e que aspirava, secretamente, a ser complexo como o universo.

\section{Coda com leitor}

Ao longo do milenário sonho da literatura, há um único personagem que persiste, que muta e se modifica mas cuja presença é constante e necessária, e que a literatura não deixa de postular. Talvez a mais autêntica história da literatura seja uma história do leitor e das múltiplas formas que adotou no tempo. Um capítulo decisivo dessa história hipotética, ocupá-lo-ia a Bíblia e suas vastas repercussões e ramificações, que talvez alcancem todos os capítulos posteriores; outro capítulo se referiria ao debate trobar clus versus trobar leu dos trovadores provençais do século XII, outro a Dante e aos quatro níveis de sentido, outro a Shakespeare, outro ao Quixote, outro a Poe e ao gênero policial, outro ao simbolismo e à poesia de Mallarmé, outro ao Ulysses de Joyce, outro à obra de Jorge Luis Borges, outro à sua prolongação nas obras de Queneau, Perec, Calvino e Roubaud, os grandes nomes do Oulipo. Uma segunda parte se ocuparia do Oriente, da poesia chinesa e as densas redes simbólicas cifradas em uns poucos versos de monossílabos pintados; da encarnação dessa poesia no Japão do período Heian e de seu mais extraordinário produto: o Genji monogatari, a que se dedicaram comentários e exegeses que enchem as bibliotecas japonesas ${ }^{43}$; e por certo também se ocuparia do que está na base da China e do Japão: o budismo da Índia e suas inesgotáveis parábolas, lidas, e depois reda-

43 Talvez nenhum outro fato tenha exercido tanta influência na evolução do romance europeu como o desconhecimento desta obra japonesa dos inícios do século XI, escrita por uma mulher da corte chamada Murasaki Shikibu, e que não se traduziu a uma língua ocidental senão com o século XX já adiantado. As conseqüências dessa demora são incalculáveis. Uma delas é a existência mesma do romance, que talvez o Genji (que prefigura o Quixote, Laurence Sterne, Jane Austen, Flaubert, Henry James, James Joyce, Marcel Proust) tivesse aniquilado. 
tadas, como jades polidos que refletem significados múltiplos e cambiantes; e do que está na base do budismo, os Vedas. Outra parte se ocuparia do Islão, encravado entre o Ocidente bíblico e o Oriente persa e hindu, cuja deslumbrante poesia se escreveu para um leitor inventado parcialmente pelo Corão, e cuja prosa oral e anônima trabalhou as incontáveis noites de magia de Sherezade, dirigidas a uma audiência, quer dizer, a um leitor, que, como o de Homero, aprendeu a preferir menos ser instruído que maravilhado.

Não importa Deus, não importa o Íon de Platão, não importam os apólogos da glossolalia, não importa a tradução segundo Walter Benjamin. Não importa a largueza do sonho da literatura, sempre poderá dizer-se dela o que Augusto Monterroso escreveu em uma só frase feliz, certeira, imodificável: "Quando despertou, o leitor todavia estava ali."

\section{Coda alternativa, cujo caráter opcional não deve distrair o leitor já que nela se o adverte sobre o potencial perigo que corre sua vida}

O leitor de Borges, depois do longo relato dedutivo, chegou (crê haver chegado) no centro do labirinto, à verdade. O leitor de Borges, entretanto, infatigável, persistente, responsável, se pergunta se não haverá algo mais: sabe que pode formular perguntas que não foram respondidas: por que o bokari? Por que Cornwall? Por que chove na primeira noite? Por que terminar o comentário em The Aleph dizendo que o modo em que "Os dois reis" se incorporou a "Abenjacan" é um mistério para ele? Por que incluir esses versos compostos e condenados por Dunraven no centro do labirinto? Isto não é matemática senão Borges, uma disciplina de elusiva verdade. E se Allaby se chama assim para que se creia que é uma pista que leva a uma solução? E se a possibilidade da terceira história não é mais que outro véu para ocultar uma quarta possibilidade, que por sua vez é o véu de uma quinta possiblidade, que por sua vez...? O leitor de Borges se pergunta se acreditando ser Teseu não será na verdade Asterion. Pergunta-se se, enquanto crê ter desfeito a teia de aranha, não haverá estado, como Unwin, senão a entretecê-la a si mesmo; perguntase, temeroso e talvez demasiado tarde, se ao final da intrincada linha reta não haverá um Scharlach que o esteve esperando desde o princípio, pronto para revelar-lhe a verdade e aniquilá-lo para sempre com um tiro quando termine de ler esta frase.

Recebido em 10 de novembro de 2008

Aprovado em 13 de fevereiro de 2009 